\title{
Effects of pH on Ensifermeliloti - Medicago sativaSymbiosis
}

\author{
Mohammed Zuhair Naji ${ }^{1 *}$ and Hassan Fadhil Naji ${ }^{2}$ \\ ${ }^{1,2}$ (Department of biology, College of Science, University of Babylon,Iraq.) \\ *This paper is part of an M.Sc. thesis of the first auther.
}

\begin{abstract}
A total of ten Ensifermeliloti were isolated from root nodules of Medicago sativa L. (alfalfa) collected from different areas of Babylon province of iraq through the period of November-2012 to February2013. The isolates were identified using polymerase chain reaction (PCR) technique, in addition to traditional methods.The PCR analysis showed that the isolates were harboured the nodbox 4 locus and the mucR genes which confirm that these isolates belong to E. meliloti.The symbiotic properties of the isolates atpH 5 - 10 were studied. It was found that the optimum $\mathrm{pH}$ for growing of Em1, Em3, Em4, Em6 and Em8 isolates was pH7, while for the remaining isolates, represented by Em2, Em5, Em7, Em9 and Em10was pH8. All isolates were able to infect the root hairs and form nodules on the roots of alfalfa plants $\left(\mathrm{Nod}^{+}\right)$at $\mathrm{pH} 7, \mathrm{pH} 7.5$ and $\mathrm{pH} 8$. The plants nodulated by these isolates were healthy and green (indicating that nitrogen was being fixed). However, the growth of isolates at pH6.5 (except for Em1 and Em8 isolates )and pH8.5 were unable to infect the root hairs and failed to elicite nodules on M. sativa (Nod).These plants were weak, stunted and became chlorotic six weeks after inoculation and resembled to the control (without inoculum) plants in all respects. These results indicate that the $\mathrm{pH}$ was significant factor and play essential role in the optimum nitrogen fixation.
\end{abstract}

Keywords:pH, Esifermeliloti ,Medicago sativa, symbiosis.

\section{Introduction}

Sinorhizobiummeliloti offered a taxonomic challenge since many years which renamed recently to Ensifermeliloti[1]. This bacterium is use as a biofertilizer to increase the crop productivity, decrease the environmental pollution and improve the soil fertility to benefit the subsequent crop. Furthermore, the cost is so low that every farmer can affored using them, and these are the best alternatives to the inorganic (synthetic) fertilizers [2]. E. melilotiis able to enter into a symbiotic association with alfalfa plantwhich can be divided into three major stages: the first stage is preinfection or recognition which includes exchange of specific signal molecules (flavonoids and Nod factors) between E. melilotiand root hairs of M. sativa, the second stage is infection with concomitant nodule formation, in this stage the host cell wall is hydrolyzed and invasion tube called infection thread is induced which carries the invading bacteria towards the base of root hair, the cells of root cortex are mitotically activated and form nodule primodium then the bacteria released from infection thread into the cytoplasm of invaded host cells and be surrounded by host-derived peribacteroid membrane which controls the nutrient transfer between the symbionts then the divided bacteria differentiate into nondividingbacteroids (symbiosomes), the last stage is nodule function, in this stage the symbiosomes be able to reduce atmospheric $\mathrm{N}_{2}$ to $\mathrm{NH}_{3}$ through the activation of the nitrogenase complex [3]. E. melilotiis a fast growing rhizobia that has a moderately small genome size of 6.7 million base pairs, the genome is still quite complex and is made up of three circular elements of DNA known as replicons, a chromosome $3.65 \mathrm{Mb}$ and two megaplasmidspSymA $1.35 \mathrm{Mb}$ and $\mathrm{pSymB} 1.68 \mathrm{Mb}$ [4]. The alfalfa plant is one of the most importantleguminous forage crops with high nutritional value and higherproduction continuing for many seasons and can be sown in spring or fall, and does best on well drained soils with a neutral levels of pH 6.8 7.5 , alfalfa requires sustained levels of potassium and phosphorus to grow well, it is moderately sensitive to salt levels in both the soil and irrigation water [5].pH is one of important environmental factors which effect on the rate of effective survival rhizobia, the changing of $\mathrm{pH}$ level means adding or subtracting hydrogen ions, changes in $\mathrm{pH}$ have the most noticeable effects on bacterial enzymes, extreme changes in the $\mathrm{pH}$ balance of the local environment for bacteria tend to kill them [6].ThepH affect the melting of some nutrient elements in the soil, as well as the rate of absorption of some elements, and inhibits the growth of some crops like alfalfa [7]. Fe is the most important element which needs in the formation of the compound leghemoglobin which plays an important role in the transfer of oxygen into the root node, the presence of oxygen in the root nodules would reduce the activity of the oxygen sensitive nitrogenase which responsible for the fixation of atmospheric nitrogen [8]. Due to the less studies in this field in Iraq, this paper aimed to isolate $E$. melilotifrom different locations of the Babylon province from roots nodules of alfalfa plants and focused on the effects of $\mathrm{pH}$ on symbiotic relationships between these parteners . 


\subsection{Bacterial isolates}

\section{Materials And Methods}

After collection of alfalfa plants from 10 different areas of Babylon province, mature pink nodules on root hairs were cut and surface sterilized using $95 \%$ of ethanol for 1 minute and washed in sterile distilled water for 5 times then the nodules were crashed with the help of glass rod in $1 \mathrm{ml}$ of physiological saline solution.The suspension was spreadedon TY media and incubated at $28{ }^{\circ} \mathrm{C}$ for 48 hours. The bacteria were identified depending on traditional methods as described by [9] , and PCR technique [10].

\subsection{Plant cultivar}

Seeds of alfalfa (M. sativaL.) plants were purchased from local markets of Hillacity,Iraqand theirplantsclassified in the lushly of Babylon University [9].

\subsection{Media for $E$. melilotiisolates}

Trypton yeast extract (TY) medium used for growing of isolates andprepared according to [11].TY swarm plates is the same as TY medium except for reduction of agar concentration to $0.3 \%$ (W/V). This medium was used to test the motility and ability of $E$. melilotiisolates to produce $\beta-(1,2)$-glugans. Mannitolsalt yeast extract medium (MSY) was used to test the ability of E. melilotiisolates to produce $\beta$-(1,3)-glugans, cellulose fibrils and lipopolysaccharides (LPS)[11].

\subsection{Media for alfalfa (M. sativa $\mathrm{L}$.) plants}

Water agar medium contained1\%(W/V) agar was used for germination of alfalfa seeds(Vincent,1970) and nitrogen free plant growth medium was used for growing of alfalfa plant [12].

\subsection{Determination of cell surface carbohydrate molecules}

To determin the cyclic $\beta$-(1,2)-glucans,the isolates were spotted on TY swarm plates[13]. $\beta$-(1,3)glucans were determined by streaking the bacterial isolates on MSY agar plates containing $0.02 \%$ (W/V) of aniline blue [14].Cellulose fibrils were determined by streaking the isolates on MSY agar plates containing $0.02 \%$ (W/V) of congo red [15].Sodium deoxycholate was added to MSY medium atthe rateof $1 \mathrm{mg} / \mathrm{ml} \mathrm{before}$ autoclaving to test the ability of isolates to produce LPS[16].All plats were incubated at $28^{\circ} \mathrm{C}$ for 2 hours.

\subsection{Molecular identification}

Whole DNA was extracted from pure culture isolates using DNA wizard genomic extraction kit (Promega, Madison, WI, USA).The materials and kit used for PCR technique are listed in Table 2.

Table 2. Materials and Kit used for PCR technique

\begin{tabular}{|l|l|}
\hline Material & Describe \\
\hline DNA Marker 100-1000bp & $\begin{array}{l}\text { DNA ladder used to determine the size of double strand DNA fragments and consists of 10 pieces } \\
(100,200,300,400,500,600,700,800,900,1000 \mathrm{bp}) .\end{array}$ \\
\hline $\begin{array}{l}\text { Go tag Green Master } \\
\text { Mix, 2X }\end{array}$ & $\begin{array}{l}\text { Cotain Go Tag DNA Polymerase , 2X Go Tag Reaction Buffer (pH 8.5), MgCl2, dATP , dTTP , } \\
\text { dCTP, dGTP. }\end{array}$ \\
\hline $\begin{array}{l}\text { Wizard Genomic } \\
\text { Extraction kit }\end{array}$ & $\begin{array}{l}\text { Used to extracte DNA from bacterial isolates and consists of cell lysis solution , nuclei lysis } \\
\text { solution, protein precipitation solution, RNase, Tris EDTA }\end{array}$ \\
\hline
\end{tabular}

The primers of PCR were synthesized by Bioneer company- Korea as described by [10].Nodbox1, nodbox3, mucRf, and mucRr were recognized homologous conserved regions in the E. melilotigenome. The conditions of PCR amplification of genomic DNA of E. melilotiwere $95^{\circ} \mathrm{C}$ for $30 \mathrm{~S}, 53^{\circ} \mathrm{C}$ for $45 \mathrm{~S}$, and $72^{\circ} \mathrm{C}$ for $30 \mathrm{~S}$ for 25 cycles, followed by 7 -min elongation step at $72^{\circ} \mathrm{C}$. Each primer was added at a concentration of $0.4 \mu \mathrm{M}$. (Table 3.)

Table 3.PCR primers and conditions used in this study. ( Bioneer company- Korea)

\begin{tabular}{|c|c|c|c|c|c|}
\hline Primer & Sequence $(5 \rightarrow)$ & $\begin{array}{l}\text { PCR Amplicon } \\
\text { (bp) }\end{array}$ & $\begin{array}{l}\text { Denaturaion, } \\
\text { AnnelingandE } \\
\text { xtension }\end{array}$ & $\begin{array}{l}\text { No. of } \\
\text { cycle }\end{array}$ & Source \\
\hline nodbox1 & TCTTTTCTTATCCATAGGGTGG & 646 & \multirow{3}{*}{$\begin{array}{l}95^{\circ} \mathrm{C} / 30 \mathrm{~S} \\
53^{\circ} \mathrm{C} / 45 \mathrm{~S} \\
72^{\circ} \mathrm{C} / 30 \mathrm{~S}\end{array}$} & \multirow{3}{*}{25} & \multirow{3}{*}{$\begin{array}{l}\text { Sanchez- } \\
\text { Contrerasetal., } \\
(2000)\end{array}$} \\
\hline mucRf & ATGACAGAGACTTCGCTCGGT & \multirow[t]{2}{*}{431} & & & \\
\hline mucRr & TCACTTGCCGCGACGCTT & & & & \\
\hline
\end{tabular}

\subsection{Preparation of reaction mixture}


The reaction mixture was prepared according to the instructions of the manufacturer (Promega USA). The total volume of reaction was $50 \mu \mathrm{L}$ consist of $12.5 \mu \mathrm{L}$ from $2 \mathrm{X}$ Go Taq Green Master Mix, $5 \mu \mathrm{L}$ from each primer, $5 \mu \mathrm{L}$ from DNA template, then the volume complete to $50 \mu \mathrm{L}$ by free nuclease water. Negative control contains all contents without DNA template was also used.

\subsection{Agarose gel electrophoresis}

The electrophoresis was performed according to[17].The PCR products were run on horizontal agarose gel (1\%) stained with ethidium bromide, for $90 \mathrm{~min}$. and 70 volt. The DNA bands were photographed by Gel documentation system (Biometra Co. Germany)

\subsection{Preparation of seedings}

Normal and undamaged seeds of alfalfa plants were selected,washedwith distilled water for 10 minutes, surface sterilized with $70 \%$ of ethanol alcohol for one minute then washed with distilled water followed by treatment with sodium hypochlorite $(\mathrm{NaOCl})$ for 15 minutes after that washedwith distilled water 3 times, spread on $1.0 \%(\mathrm{w} / \mathrm{v})$ water agar medium and incubated inverted at $25^{\circ} \mathrm{C}$ for two days in dark place [9].

\subsection{Plant tests and growth conditions}

Three healthy grown seedlings with two days old transferred to the slants of nitrogen free plant growth medium with different $\mathrm{pH}$ (pH6.5, $\mathrm{pH} 7, \mathrm{pH} 7.5$, $\mathrm{pH} 8$ and $\mathrm{pH} 8.5$ ) in $30 \mathrm{X} 2.5 \mathrm{~cm}$ glass tube containing $25 \mathrm{ml}$ of this medium [12].The lower portion of each tube was wrapped with black paper to prevent the root system from exposure to light. These tubes were incubated in plant growth chamber (Memmert, Germany) under conditions $25^{\circ} \mathrm{C}, 70-80 \%$ humidity and 2000 lux of visible light for six weeks. 16 hours light and 8 hours dark cycle were maintained. $0.5 \mathrm{ml}$ of E. melilotiisolate cells suspension was dispensed into each tube having three days old seedlings. Control tubes containing three seedlings each received $0.5 \mathrm{ml}$ of physiological saline solution. Three tubes containing three seedlings each were used for each tretment. Many parameters characteristic of each plant were recorded such as time of appearance of first nodule , nodule number, nodule shape, nodule colours, shoot length and shoot dry weight.Tomeasure the latter, plant shoots were collected, dried in an oven at $60 \mathrm{C}^{\circ}$ for three daysand then weighted. Nitrogen fixation was indirectly evaluated by scoring the plants Fix ${ }^{+}$or Fix ${ }^{-}$on the basis of nodule colour and/or plant matter production [2].

\subsection{Alfalfa root hair deformations}

The root hairs of 4-10 days old plants after inoculation with isolates were removed, washed with sterile water and cut into $1 \mathrm{~cm}$ long pieces . The root pieces were stained with methylene blue $(0.01 \% \mathrm{~W} / \mathrm{V})$ for 15 minutes, washed with sterile water, place on clean glass slide and covered with cover slip and then examined at 10X and 40X magnifications under light microscope for observing root hair deformations (curling, waviness ,bulging and swelling, shepherd's crook with hyaline spot, formation of infection thread and formation of nodules [18]

\subsection{2pH optimization}

Different concentrations of hydrogen ion ( $\mathrm{pH} 5, \mathrm{pH} 6, \mathrm{pH} 7, \mathrm{pH} 8, \mathrm{pH} 9$ and $\mathrm{pH} 10)$ in Ty medium were used.Each plate inoculated with $0.1 \mathrm{ml}$ of bacterial isolates(approximately contain $3 \times 10^{5} \mathrm{CFU} / \mathrm{ml}$ )using pour plating techniqueandincubatedat $28^{\circ} \mathrm{C}$ for 48 hours[19].

\subsection{Statistical analysis}

For analysis the data that collection from this study, one way ANOVA test which described by [20].was used for this purpose, all values were expressed as mean \pm standard error of mean.

\subsection{Isolation of $E$. melilotiisolates}

\section{Results And Discussion}

A total of ten local isolates of E.melilotiwere isolated from root nodules of M. sativiaL. from different areas of Babylon province. These isolates were chosen for the further experimsents.Thenumber, name and place of isolates are listed in Table1. 
Table 1 .Number, name and place of bacterial isolates .

\begin{tabular}{|l|l|l|}
\hline No. of Isolate & Name of Isolate & Place of Isolates \\
\hline 1 & Em1 & Hilla-AljazaeerQuartar \\
\hline 2 & Em2 & Hilla-Babylon university \\
\hline 3 & Em3 & Babylon-Nile area \\
\hline 4 & Em4 & Babylon-Abo garaq area \\
\hline 5 & Em5 & Babylon-Almethateya area \\
\hline 6 & Em6 & Babylon-Almahaweel area \\
\hline 7 & Em7 & Babylon-Alkefel area \\
\hline 8 & Em8 & Babylon-Alqasim area \\
\hline 9 & Em9 & Babylon-Indian dam area \\
\hline 10 & Em10 & Hilla-Alwardia area \\
\hline
\end{tabular}

\subsection{Identification of $E$. melilotiisolates}

The isolates were identified depending on morphological properties of the cells and colonies of these isolates, and thecell surface carbohydrate molecules (Fig. 1.).
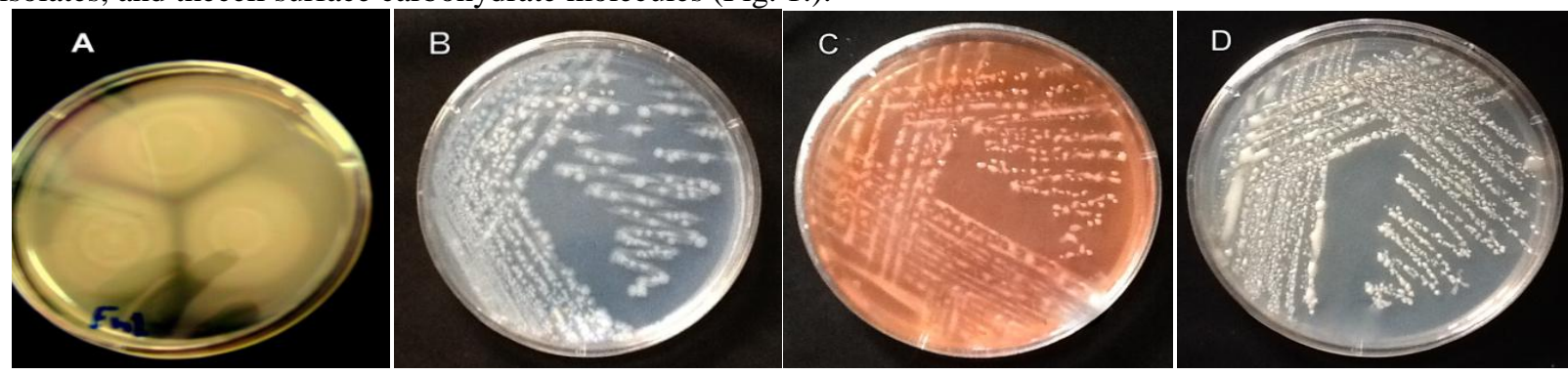

Figure1 .Production of cell surface carbohydrate molecules of E.meliloti isolates.

A. Cyclic $\beta-(1,2)$-glucansproduction showed swarming on swarm plates. B. $\beta-(1,3)-$

glucansproductionwhichdid not show binding with aniline blue dye on MSY medium.C. Cellulose fibrilsproductionshowed red colonies due to took up congo red dye on MSY medium.D. LPSproductionshowed growth on MSY medium containing sodium deoxycholate.

All bacterial isolates showed swarming on swarm plates therefore, these isolates were motile and had ability to produce of cyclic $\beta$-(1,2)-glucans. The isolates did not uptake aniline bluedye and unable to produce of $\beta$-(1,3)-glucans. Rhizobial cell surface is a complex conglomerate of various polysaccharides that play a major role in the development of symbiotic nodules. [21].found that only E. melilotiwas unable to produce $\beta$ $(1,3)$-glucans but all rhizobia can produce $\beta$ - $(1,2)$-glucans. The absence of cyclic glucan synthesis affect the invasion capacity of the bacteria,mutantsdefective in the synthesis of this polysaccharide induce empty nodules and did not induce the formation of the infection threads [13] [22].The isolates were uptake congo red dye and showed red colonies due to produce of cellulose fibrils.[23] , showedthatcongo red absorption has been used as amarkerfor identification of rhizobia.The isolates were able to utilized sodium deoxycholate and produced lipopolysaccharide .[24].found that mutation in production of LPS of E. meliloticaneffect its ability to utilize sodium deoxycholate. [25]reported that the O-antigen structure was changed when rhizobia subjected to seed or root compounds. During the differentiation of the bacterium into bacteroid, LPS undergoes changes in its structure [26].A general observation is that the LPS changes during symbiosis lead to an increasing of surface hydrophobicity that influence the interaction between bacterial and plant cell membranes and could be relevant for the sincronic division bacteoid / symbiosome[27] [28]. The molecular identification of E. melilotiusingPCR technique (Fig. 2) showedtwo regions of the E. melilotigenome: the nodbox 4 promoter and the mucR gene. Both of these regions are specific for E. melilotiand are highly conserved and ubiquitous in the species[29].Furthermore, they are located in different replicons; the nodbox 4 region is located in one of the symbiotic megaplasmids[30], and mucR is located in the chromosome [31].Simultaneous detection of both regions should increase the specificity of the method compared to methods based on use of a single primer pair. The nodbox 4 region was amplified using primers nodbox1 and nodbox3. [10]found that PCR amplification of the nodbox andmucRloci is a reliable and rapid method for identification of E. melilotistrains (when primers nodbox 1 , nodbox 3 , mucRf, and mucRr were used simultaneously the product was two discrete bands at 646 and $431 \mathrm{bp}$ were amplified from all of the E. melilotistrains), especially when high numbers of other bacteria are expected to be presented in nodules. Therefore, this technique can be used to generate a strain collection from field samples with reduced laboratory effort in a short period of time. Furthermore, the two amplicons used in this study added new probes to those already available for identification of E. meliloti. Optimization of this PCR procedure allowed simultaneous detection of the two loci with a single PCR 


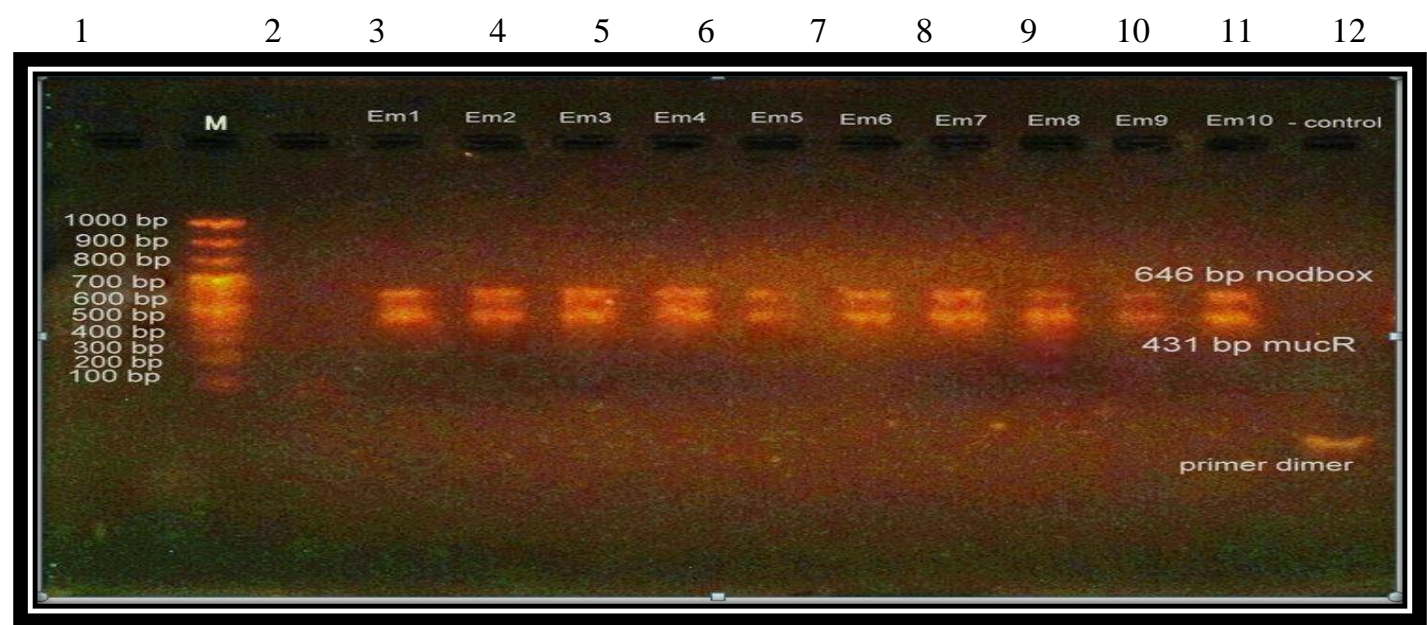

Figure 2 .Agarosegelectrophoresis of the amplified products of E. melilotiisolates on (1\%) agarose gel for 90 min. and $70 \mathrm{~V}$. Lane 1 : ladder $1 \mathrm{~Kb}$.Lanes 2 to 11 : Em1 to Em10, respectively.Lane 12 : negative control.

\subsection{Infection phenotypes on alfalfa root hairs and formation of nodules}

When the methylene blue stained root portions of alfalfa plant inoculated with isolates, observed under light microscope, it was found that all isolates werenormal in elicitation of root hair deformations, shepherd's crook with hyaline spote, infection thread and formation of nodules. However, the root hairs of uninoculated controls were straight and devoid of the infection phenotypes (Plats 1 and 2).The symbiotic interaction starts when the bacteria colonize the root surface and induce curling of the root hair tips,this is followed by cell wall invagination and the formation of an infection thread that grows within the root hair[32] [33].

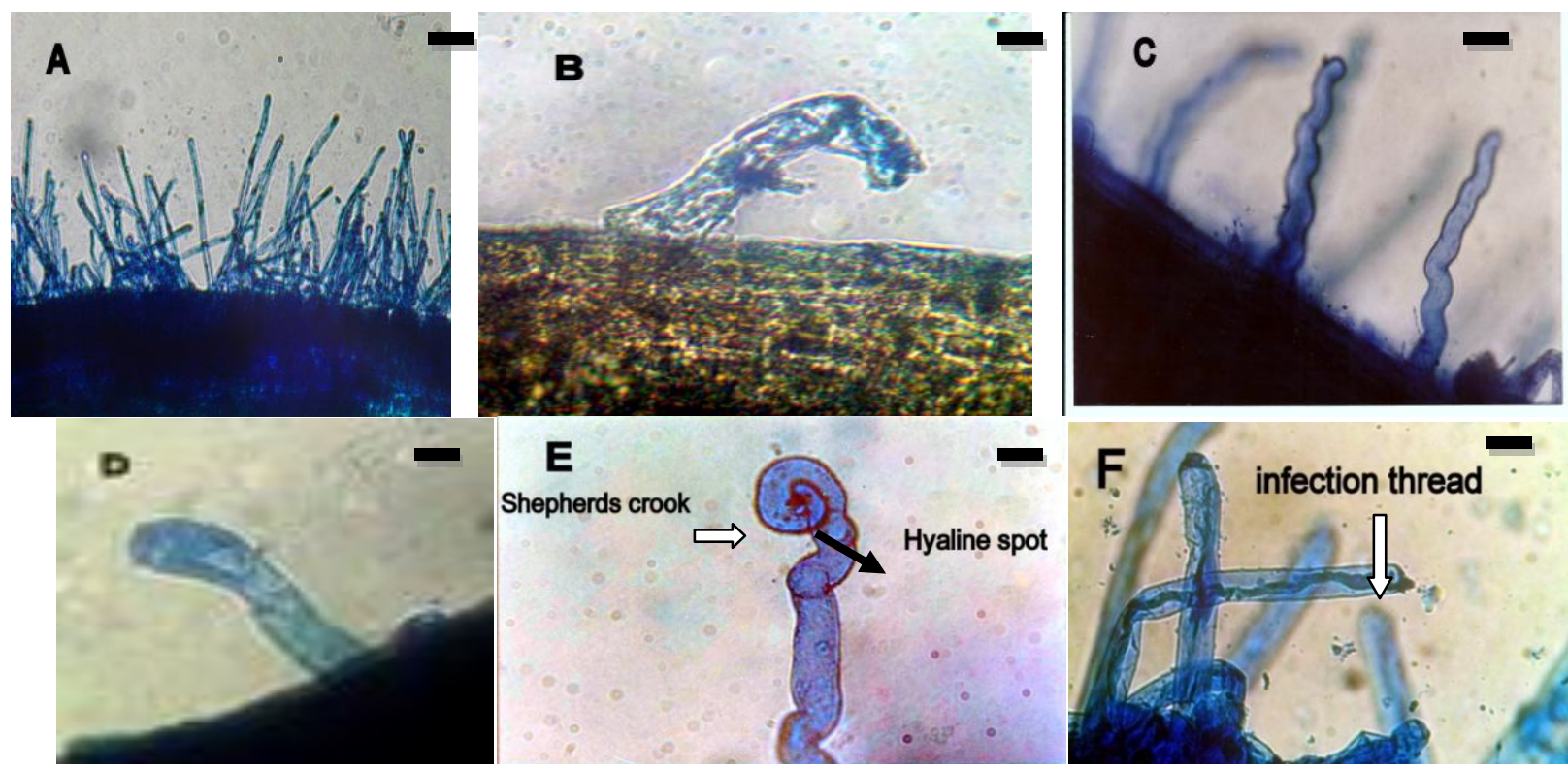

Plate 1 . Light microscopic observations of root hairs of M. sativa L. after 4- 10 days of inoculated with E. melilotiisolates . A. Uninoculated control showing intact, straight root hairs. B. Curling root hair. C. Waviness root hair. D. Bulging or swelling root hair. E. Formation of shepherd,s crook showing the $360^{\circ}$ curvature of the root hair tip with hyaline spot F. Infection thread formation which elongation at the base of the root hair cell. Bars: A, $100 \mu \mathrm{m}(\mathrm{X} 100)$; B,C,D,Eand F, 25 $\mu \mathrm{m}$ (X400).

The infection thread traverses the outer cell layers to reach the nodule primordium, which isinitiated by the reactivation of differentiated cells of the root cortex for division. Within the infection thread the rhizobia multiply but remain confined by the plant cell wall. As the primordium develops to a nodule, bacteria are released from the tip of the infection thread by endocytosis and differentiate into bacteroids surrounded by the peribacteroid membrane, this process will continue to form a mature nodules. The symbiotic interaction involves an exchange of complex molecular signals that confer specificity. Legume roots and seeds exude different substances: sugars, amino acids, dicarboxilic acids and various aromatic compounds such as some 
flavonoids in mixtures that differ between species [34]. Rhizobia respond to these compounds because they have one or more nodD genes, which encode regulator proteins that activate the other nod genes when they interact with appropriate plant signal compounds. Once activated, the nod genes direct the synthesis of Nod factors (NF), a family of lipochitin oligomers (LCO), which acting as morphogens, initiating the nodulation program of the host plant [35] [36].The induction of nitrogen-fixing root nodules on leguminous plants by rhizobia requires multiple interactions between the two partners. In different Rhizobium and Bradyrhizobium species, several gene sets (nod genes) have been identified which control the early steps of nodulation [37].The common nodulation genes (nodABC) are essential and conserved in all rhizobia, both functionally and at the DNA sequence level[38]. Other sets of genes determine the host-specificity of nodulation (hsnABCD genes) [39].

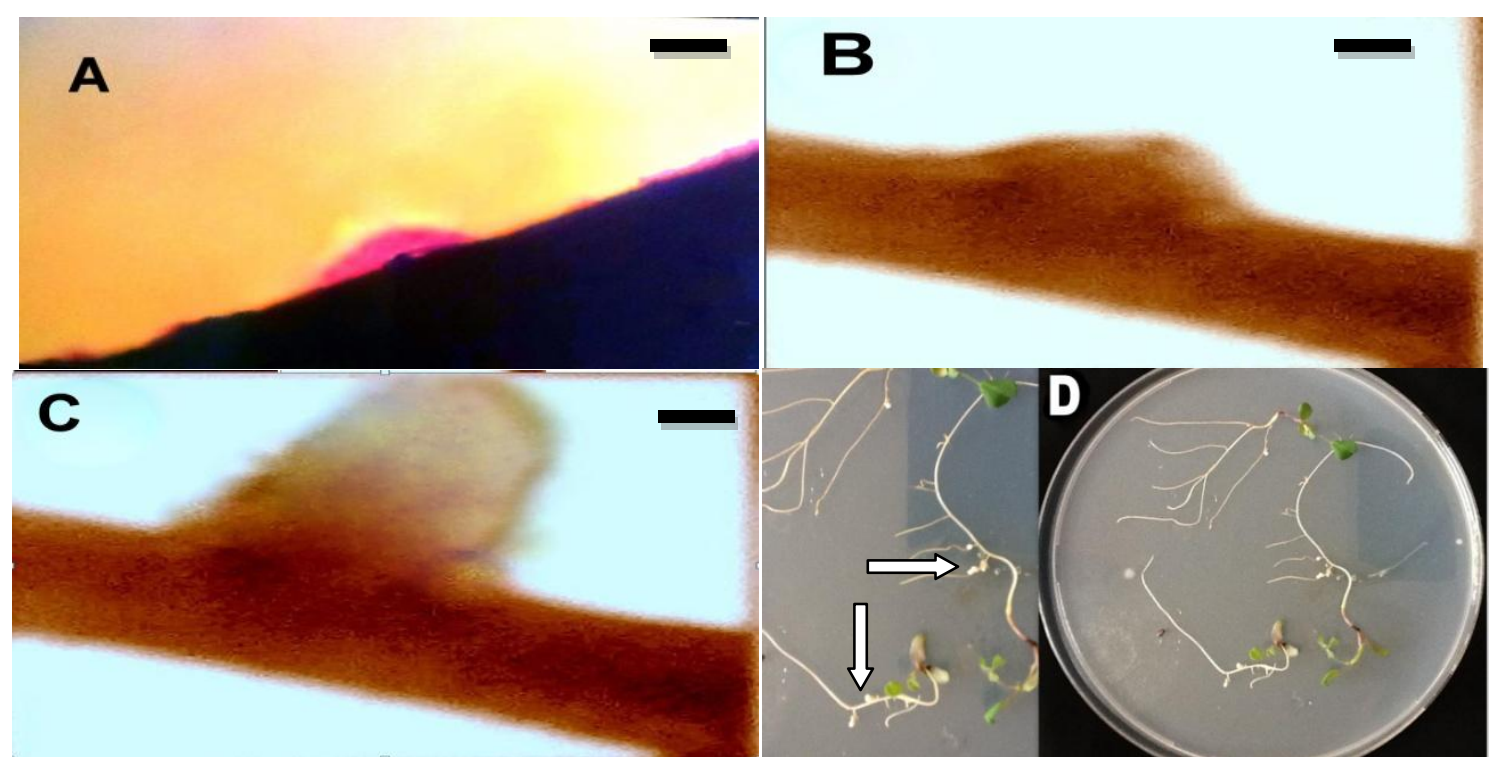

Plate 2 . Light microscopic observations of root hairs of $M$. sativa L. after 2-4 weeks of inoculated with $\mathrm{E}$. meliloti. A, B and C. Intiation nodule structure.D.formation of nodules.Bars: A,B and C, $25 \mu \mathrm{m}$ (X400); The arrows in $\mathrm{E}$, indicate the positions of the nodules.

\subsection{Effect of pH on growth of E. melilotiisolates}

The bacterial isolates have a range of $\mathrm{pH}$ 6-10 except for Em1 and Em8 isolates have ability to growth on $\mathrm{pH} 5$, the $\mathrm{pH}$ of isolates Em1, Em3, Em4, Em6 and Em8 was pH7 and for remaining isolates was pH8 (Fig.3).[40] showedthatacid pH limits the persistence of Rhizobium strains in soil, and the nodulation and nitrogen fixation of legumes, they tested the ability of 45 Rhizohirrm, Azorhizohirrm and Bradyrhizobium strains to produce colonies on agar medium at $\mathrm{pH} 4$ to $\mathrm{pH} 7$,only $\mathrm{R}$. tropici UMRI 899 grew at $\mathrm{pH} 4 \mathrm{in}$ unbuffered medium, though 6 strains of R. tropici and 3 Bradyrhizobium strains grew at $\mathrm{pH} 4.25$, and 15 strains grew at $\mathrm{pH} 4.5$.

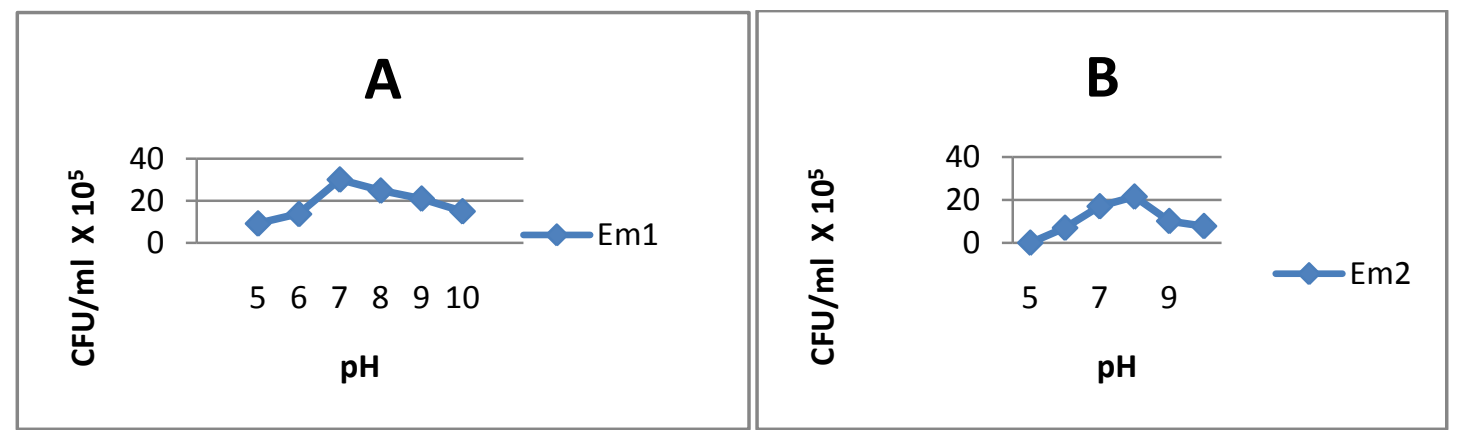




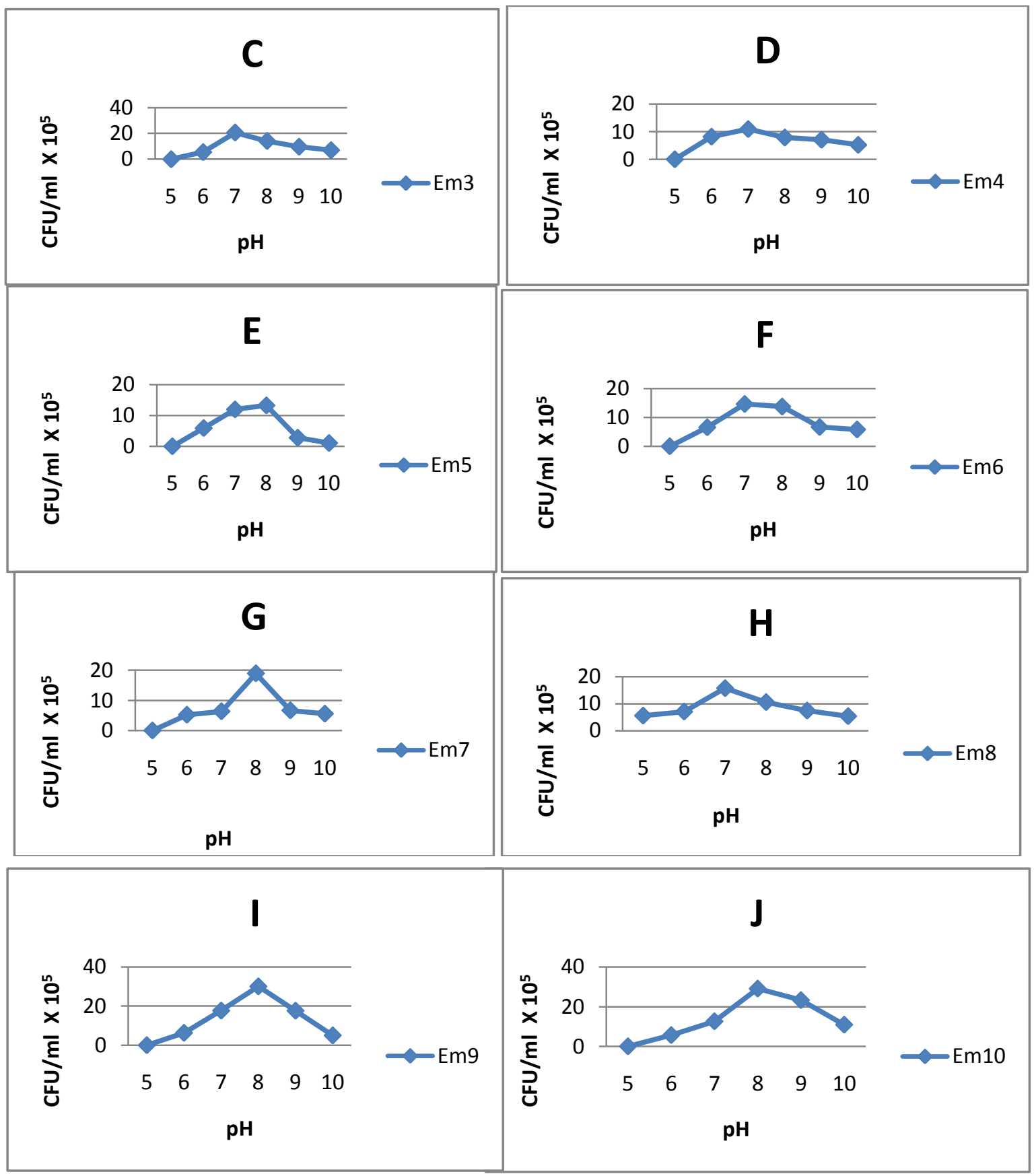

Figure 3 . Effect of $\mathrm{pH}$ on growth of E. melilotiisolates incubated at $28^{\circ} \mathrm{c}$ for 48 hours.

\subsection{Characteristics of alfalfa plants nodulated by $E$. melilotiisolates at different $\mathrm{pH}$.}

The nodule and shoot characteristics of alfalfa plants nodulated by the E. melilotiisolates are given in Table 5,6,7,8 and 9. The data presented in these Tables are being listed only after reisolation of the particular isolate from nodules and checking for their markers (Koch's postulate).Em2, Em3, Em4, Em5 , Em6 , Em7, Em9 and Em10 isolates at $\mathrm{pH} 6.5$ and all isolates at $\mathrm{pH} 8.5$ did not form nodules on the roots of alfalfa plants. The isolates Em1 and Em8 at pH 6.5; Em2, Em3 , Em4, Em5, Em6, Em7 and Em10 isolates at pH 7; Em3, $\mathrm{Em} 9$ and Em10 isolates at pH 7.5 and Em1, Em3, Em5, Em6, Em7, Em8 and Em9 isolates at pH 8formed small and white (suggesting a lack of leghaemoglobin) nodules on the roots of alfalfa plants that were symbiotically ineffective.The remaining isolates elicited normal, cylindrical and pink (indicating the presence of leghaemoglobin) nodules on roots of alfalfa plants that were symbiotically fully effective. The mean height and dry shoot weight of plants nodulatedby Em1, Em5, Em6, Em8 and Em9 isolates at pH 7; Em1-Em10isolates at $\mathrm{pH} 7.5$ and $\mathrm{Em} 2, \mathrm{Em} 3, \mathrm{Em} 4$ and Em10 isolates at $\mathrm{pH} 8$ differed significantly with the uninoculated controls $(\mathrm{P}<0.05)$.These plants appeared healthy and green (indicating that nitrogen was being fixed).The mean time 
taken for the appearance of first nodule after inoculation with the isolates ranged from 8 days for Em2 isolate at $\mathrm{pH} 7.5$ to 21.6 days for Em8 isolate at $\mathrm{pH}$ 6.5; mean number of nodules per plant varied from 0.6for Em8 isolate at $\mathrm{pH} 6.5$ to 11.3 for Em6 isolate at $\mathrm{pH} 7$; mean shoot length per plant differed from $2.3 \mathrm{cmforEm} 3$ isolate at $\mathrm{pH}$ 6.5 to $18.5 \mathrm{~cm}$ for Em8 isolate at $\mathrm{pH} 7.5$, whereas $8.3 \mathrm{~cm}$ for the uninoculated controls at $\mathrm{pH} 7.5$; mean dry shoot weight per plant varied from $3 \mathrm{mgforEm} 4$ isolate at $\mathrm{pH} 6.5$ to $18.6 \mathrm{mgforEm6}$ isolate at $\mathrm{pH} 7.5$, whereas $7.6 \mathrm{mg}$ for the uninoculated controls at $\mathrm{pH}$ 7.5. [41] showed soil acidification is one of the environmental factors that more strongly hampers the establishment of an effective symbiotic interaction between rhizobia and leguminous plants. E. melilotiand the acid-tolerant Rhizobium sp. strain LPU83 are able to nodulate alfalfa plants at $\mathrm{pH} 5.6$ but both exhibit a delayed nodulation and a reduction in the number of elicited nodules. [42] found that collection of 465 isolates of rhizobia were characterized for acid tolerance revealed the existence of 15 acid-tolerant isolates which were able to grow at $\mathrm{pH} 5.0$ and formed nodules in alfalfa with a low rate of nitrogen fixation.[43]reported that biological nitrogen fixation is a phenomenon occurring in all known ecosystems and thesymbiotic nitrogen fixation is dependent on the host plant genotype, the rhizobia strains and the interaction of these symbionts with the pedoclimatic factors and the environmental conditions.However,extremes of $\mathrm{pH}$ affect nodulation due to reducing the colonization of soil and the legume rhizospher. Highly alkaline soils $(\mathrm{pH}>8)$ tend to be high in sodium chloride, bicarbonate, and borate, and are often associated with high salinity which reduce nitrogen fixation and highly acidic soils $(\mathrm{pH}<4)$ frequently have low levels of phosphorus, calcium, and molybdenum and high concentrations of aluminium and manganese which are often toxic for both partners; nodulation is more affected than host-plant growth and nitrogen fixation.

Table 5. Effect of pH6.5 on the symbiotic relationship between alfalfa plants and bacterial isolate

\begin{tabular}{|l|l|l|l|l|l|l|}
\hline \multirow{2}{*}{$\begin{array}{l}\text { Bacteral } \\
\text { isolate }\end{array}$} & $\begin{array}{l}\text { Time of first nodule } \\
\text { appearance in days } \\
\text { (mean } \pm \text { SE) }\end{array}$ & $\begin{array}{l}\text { Nodule/plant } \\
\text { (mean } \pm \text { SE) }\end{array}$ & Shape & Colour & $\begin{array}{l}\text { Shoot length } \\
\text { cm/plant } \\
\text { (mean } \pm \text { SE) }\end{array}$ & $\begin{array}{l}\text { Dry shoot } \\
\text { weight } \\
\text { mg/plant } \\
\text { (mean } \pm \text { SE) }\end{array}$ \\
\hline $\begin{array}{l}\text { Control } \\
\text { (no } \\
\text { inoculum) }\end{array}$ & Nil & Nil & Nil & Nil & $3.6 \pm 0.3$ & $4.3 \pm 0.8$ \\
\hline Em1 & $20.3 \pm 1.4$ & $1 \pm 0.5$ & Irregular & White & $4.3 \pm 0.6$ & $4.6 \pm 0.3$ \\
\hline Em2 & Nil & Nil & Nil & Nil & $3 \pm 1.1$ & $4.6 \pm 0.6$ \\
\hline Em3 & Nil & Nil & Nil & Nil & $2.3 \pm 0.3$ & $3.6 \pm 0.3$ \\
\hline Em4 & Nil & Nil & Nil & Nil & $3.3 \pm 0.6$ & $3 \pm 0.5$ \\
\hline Em5 & Nil & Nil & Nil & Nil & $3 \pm 0.5$ & $3.6 \pm 0.3$ \\
\hline Em6 & Nil & Nil & Nil & Nil & $3.6 \pm 0.4$ & $4.6 \pm 0.6$ \\
\hline Em7 & Nil & $0.6 \pm 0.3$ & Irregular & White & $4 \pm 0.5$ & $4.3 \pm 0.3$ \\
\hline Em8 & $21.6 \pm 1.1$ & Nil & Nil & Nil & $2.6 \pm 0.6$ & $3.3 \pm 0.3$ \\
\hline Em9 & Nil & Nil & Nil & Nil & $3.6 \pm 0.8$ & $4.3 \pm 0.8$ \\
\hline Em10 & Nil & & & & $4.6 \pm 0.3$ \\
\hline
\end{tabular}

Each value is a mean of three plants \pm standard error .

Table 6. Effect of pH7 on the symbiotic relationship between alfalfa plant and bacterial isolates .

\begin{tabular}{|l|l|l|l|l|l|l|}
\hline \multirow{2}{*}{$\begin{array}{l}\text { Bacteral } \\
\text { isolate }\end{array}$} & $\begin{array}{l}\text { Nodule characteristics } \\
\text { appearancein days } \\
\text { (mean } \pm \text { SE) }\end{array}$ & $\begin{array}{l}\text { Nodule/plant } \\
\text { (mean } \pm \text { SE) }\end{array}$ & Shape & Colour & $\begin{array}{l}\text { Shoot length } \\
\text { cm/plant } \\
\text { (mean } \pm \text { SE) }\end{array}$ & $\begin{array}{l}\text { Dry shoot } \\
\text { weight } \\
\text { mg/plant } \\
\text { (mean } \pm \text { SE) }\end{array}$ \\
\hline $\begin{array}{l}\text { Control } \\
\text { (no } \\
\text { inoculum) }\end{array}$ & Nil & Nil & Nil & Nil & $3.3 \pm 0.8$ & $5.3 \pm 0.8$ \\
\hline Em1 & $\mathbf{1 5 \pm 1 . 5}$ & $4.3 \pm 1.2$ & Cylindrical & Pink & $7.6 \pm 0.8 *$ & $10.6 \pm 0.8 *$ \\
\hline Em2 & $15.3 \pm 1.2$ & $1.3 \pm 0.3$ & Irregular & White & $3 \pm 0.5$ & $3.3 \pm 0.8$ \\
\hline Em3 & $15.6 \pm 0.8$ & $3.3 \pm 0.6$ & Irregular & White & $4.6 \pm 0.8$ & $6.6 \pm 1.2$ \\
\hline Em4 & $16 \pm 1.1$ & $3.6 \pm 0.8$ & Irregular & White & $5.3 \pm 1.3$ & $7 \pm 1$ \\
\hline
\end{tabular}


Effects of pH on Ensifermeliloti - Medicago sativa Symbiosis

\begin{tabular}{|l|l|l|l|l|l|l|}
\hline Em5 & $16.6 \pm 0.8$ & $2.3 \pm 0.8$ & Irregular & White & $7 \pm 1.5 *$ & $9.3 \pm 1.2 *$ \\
\hline Em6 & $15.3 \pm 0.6$ & $3 \pm 0.5$ & Irregular & White & $8.6 \pm 0.8 *$ & $10.6 \pm 1.4 *$ \\
\hline Em7 & $\mathbf{1 7 . 3} \pm \mathbf{O . 3}$ & $1.6 \pm 0.3$ & Irregular & White & $4 \pm 0.5$ & $5 \pm 0.5$ \\
\hline Em8 & $16.6 \pm 1.4$ & $4 \pm 1.5$ & Cylindrical & pink & $9 \pm 1.1 *$ & $7 \pm 1.1 *$ \\
\hline Em9 & $\mathbf{1 5 . 3} \pm \mathbf{0 . 8}$ & $2.6 \pm 0.8$ & Cylindrical & pink & $10.6 \pm 1 *$ & $10.3 \pm 1.2 *$ \\
\hline Em10 & $\mathbf{1 4 . 6 \pm 1 . 3}$ & $1.6 \pm 0.6$ & Irregular & White & $3.6 \pm 0.6$ & $4.3 \pm 0.4$ \\
\hline
\end{tabular}

Each value is a mean of three plants \pm standard error $*$ Significant difference with control $(\mathrm{p}<0.05)$.

Table 7. Effect of pH7.5 on the symbiotic relationship between alfalfa plant and bacterial isolates .

\begin{tabular}{|c|c|c|c|c|c|c|}
\hline \multirow{2}{*}{$\begin{array}{l}\text { Bacteral } \\
\text { isolate }\end{array}$} & \multicolumn{4}{|c|}{ Nodule characteristics } & \multicolumn{2}{|c|}{ Shoot characteristics } \\
\hline & $\begin{array}{l}\text { Time of first } \\
\text { nodule } \\
\text { appearance in } \\
\text { days } \\
(\text { mean } \pm \mathrm{SE})\end{array}$ & $\begin{array}{l}\text { Nodule/plant } \\
(\text { mean } \pm \text { SE) }\end{array}$ & Shape & Colour & $\begin{array}{l}\text { Shoot length } \\
\text { cm/plant } \\
(\text { mean } \pm \text { SE) }\end{array}$ & $\begin{array}{l}\text { Dryshoot weight } \\
\text { mg/plant } \\
\text { (mean } \pm \text { SE) }\end{array}$ \\
\hline $\begin{array}{l}\text { Control } \\
\text { (no } \\
\text { inoculum) }\end{array}$ & Nil & Nil & Nil & Nil & $8.3 \pm 0.3$ & $7.6 \pm 0.3$ \\
\hline Em1 & $9.6 \pm 0.8$ & $8.6 \pm 1.2$ & Cylindrical & Pink & $11.3 \pm 1.2 *$ & $12.3 \pm 0.6 *$ \\
\hline Em2 & $8 \pm 0.5$ & $10.3 \pm 1.4$ & Cylindrical & pink & $15 \pm 1.5 *$ & $15.6 \pm 1.8 *$ \\
\hline Em3 & $8.6 \pm 0.3$ & $9 \pm 1$ & Irregular & White & $14.6 \pm 1.3 *$ & $16.6 \pm 0.6 *$ \\
\hline Em4 & $10.3 \pm 0.8$ & $7 \pm 0.5$ & Cylindrical & pink & $17.3 \pm 1.2 *$ & $17.6 \pm 1.2 *$ \\
\hline Em5 & $10.6 \pm 0.8$ & $8.3 \pm 0.3$ & $\begin{array}{l}\text { Cylindrical } \\
\end{array}$ & pink & $17.3 \pm 0.3 *$ & $18.3 \pm 1.6 *$ \\
\hline Em6 & $9.3 \pm 0.8$ & $11.3 \pm 0.8$ & Cylindrical & pink & $17.6 \pm 1.3 *$ & $18.6 \pm 0.8 *$ \\
\hline Em7 & $9.3 \pm 0.3$ & $8.6 \pm 1.2$ & Cylindrical & pink & $15.6 \pm 0.3 *$ & $16.6 \pm 1.2 *$ \\
\hline Em8 & $8.6 \pm 0.8$ & $7.6 \pm 1.3$ & Cylindrical & pink & $18 \pm 0.5 *$ & $19 \pm 0.8 *$ \\
\hline Em9 & $8.3 \pm 0.3$ & $7.3 \pm 0.8$ & Irregular & White & $15.3 \pm 0.5 *$ & $10 \pm 0.5 *$ \\
\hline$\overline{\text { Em10 }}$ & $10 \pm 0.8$ & $9 \pm 0.5$ & Cylindrical & White & $12.6 \pm 1.2 *$ & $14.3 \pm 0.8 *$ \\
\hline
\end{tabular}

Each value is a mean of three plants \pm standard error .* Significant difference with $\operatorname{control}(\mathrm{p}<0.05)$.

Table 8.Effect of PH8 on the symbiotic relationship between alfalfa plant and bacterial isolates.

\begin{tabular}{|c|c|c|c|c|c|c|}
\hline \multirow{2}{*}{$\begin{array}{l}\text { Bacteral } \\
\text { isolate }\end{array}$} & \multicolumn{4}{|c|}{ Nodule characteristics } & \multicolumn{2}{|c|}{ Shoot characteristics } \\
\hline & $\begin{array}{l}\text { Time of first } \\
\text { nodule } \\
\text { appearance in } \\
\text { days } \\
(\text { mean } \pm \mathrm{SE} \text { ) }\end{array}$ & $\begin{array}{l}\text { Nodule/plant } \\
(\text { mean } \pm \text { SE) }\end{array}$ & Shape & Colour & $\begin{array}{l}\text { Shoot length } \\
\text { cm/plant } \\
(\text { mean } \pm \text { SE) }\end{array}$ & $\begin{array}{l}\text { Dry shoot weight } \\
\text { mg/plant } \\
\text { (mean } \pm \text { SE) }\end{array}$ \\
\hline $\begin{array}{l}\text { Control } \\
\text { (no } \\
\text { inoculum) }\end{array}$ & Nil & Nil & Nil & Nil & $6.3 \pm 0.8$ & $8.3 \pm 0.3$ \\
\hline Em1 & $9.3 \pm 0.1$ & $4.6 \pm 0.6$ & Cylindrical & White & $7.6 \pm 0.3$ & $10 \pm 1.1$ \\
\hline Em2 & $10 \pm 0.4$ & $6 \pm 0.5$ & Cylindrical & Pink & $10.3 \pm 0.8 *$ & $11.3 \pm 0.6 *$ \\
\hline Em3 & $9.3 \pm 0.7$ & $6 \pm 1$ & Irregular & White & $9.6 \pm 1.2 *$ & $11.6 \pm 0.8 *$ \\
\hline Em4 & $9.6 \pm 0.9$ & $5 \pm 1.1$ & $\begin{array}{l}\text { Cylindrical } \\
\end{array}$ & $\begin{array}{l}\text { Pink } \\
\end{array}$ & $10.6 \pm 0.8 *$ & $11.3 \pm 1.2 *$ \\
\hline Em5 & $9.3 \pm 0.7$ & $4.3 \pm 0.3$ & Irregular & White & $8.3 \pm 0.3$ & $8.6 \pm 0.3$ \\
\hline Em6 & $10 \pm 0.9$ & $4.6 \pm 0.8$ & Cylindrical & White & $7 \pm 1.1$ & $9.3 \pm 0.8$ \\
\hline Em7 & $9.6 \pm 0.9$ & $4.6 \pm 0.3$ & Cylindrical & White & $7.6 \pm 0.8$ & $9 \pm 0.5$ \\
\hline Em8 & $10.3 \pm 0.9$ & $4 \pm 1.1$ & Cylindrical & White & $7.6 \pm 0.3$ & $8.3 \pm 0.3$ \\
\hline Em9 & $11.6 \pm 0.7$ & $5 \pm 0.5$ & Irregular & White & $8.6 \pm 0.6$ & $10 \pm 0.5$ \\
\hline Em10 & $11 \pm 0.4$ & $7.3 \pm 0.3$ & Cylindrical & Pink & $13.6 \pm 0.3 *$ & $15 \pm 0.5 *$ \\
\hline
\end{tabular}


Each value is a mean of three plants \pm standard error .* Significant difference with control $(\mathrm{p}<0.05)$.

Table 9. Effect of PH8.5 on the symbiotic relationship between alfalfa plant and bacterial isolates .

\begin{tabular}{|l|l|l|l|l|l|l|}
\hline \multirow{2}{*}{$\begin{array}{l}\text { Bacteral } \\
\text { isolate }\end{array}$} & $\begin{array}{l}\text { Nodule characteristics } \\
\text { nodule appearance } \\
\text { in days } \\
\text { (mean } \pm \text { SE) }\end{array}$ & $\begin{array}{l}\text { Nodule/plant } \\
\text { (mean } \pm \text { SE) }\end{array}$ & Shape & Colour & $\begin{array}{l}\text { Shoot length } \\
\text { cm/plant } \\
\text { (mean } \pm \text { SE) }\end{array}$ & $\begin{array}{l}\text { Dry shoot weight } \\
\text { mg/plant } \\
\text { (mean }\end{array}$ \\
\hline $\begin{array}{l}\text { Control } \\
\text { no } \\
\text { inoculums) }\end{array}$ & Nil & Nil & Nil & Nil & $5.6 \pm 0.3$ & $6 \pm 0.8$ \\
\hline Em1 & Nil & Nil & Nil & Nil & $3 \pm 0.5$ & $4 \pm 0.5$ \\
\hline Em2 & Nil & Nil & Nil & Nil & $4.3 \pm 0.8$ & $4.6 \pm 0.8$ \\
\hline Em3 & Nil & Nil & Nil & Nil & $5 \pm 0.5$ & $5.6 \pm 0.6$ \\
\hline Em4 & Nil & Nil & Nil & Nil & $6 \pm 1$ & $6.6 \pm 0.8$ \\
\hline Em5 & Nil & Nil & Nil & Nil & $5.6 \pm 1.2$ & $6 \pm 0.5$ \\
\hline Em6 & Nil & Nil & Nil & Nil & $5.3 \pm 0.8$ & $5 \pm 0.5$ \\
\hline Em7 & Nil & Nil & Nil & Nil & $4.6 \pm 0.3$ & $5 \pm 0.5$ \\
\hline Em8 & Nil & Nil & Nil & Nil & $5.3 \pm 1.2$ & $6 \pm 1.1$ \\
\hline Em9 & Nil & Nil & Nil & Nil & $5.6 \pm 1.2$ & $6 \pm 0.5$ \\
\hline Em10 & Nil & & & & \\
\hline
\end{tabular}

Each value is a mean of three plants \pm standard error .

\section{Conclusion}

It is concluded that all bacterial isolates in this study were neutrophilesor little alkaliphilesand did not show any acidophilic isolates, because most of the Iraq soil in the center and south of Iraqwere alkaline due to the high rate of insoluble ions. However, still there are many gaps in our knowledge about nitrogen fixing bacteria in Iraq which needs farther investigations.

\section{References}

[1] Young, M. J.,Sinorhizobium versus Ensifer: may a taxonomy subcommittee of the ICSP contradict the Judicial Commission,International Journal of Systimatic and Evolutionary Microbiology, 60(7),2010:1711-1713.

[2] Naji, H. F., TheRhizobiumleguminosarumbv. trifoliitrp E(G) gene is essential for nitrogen fixsation. J. Col. Edu. 2(3),2008:42-46.

[3] McDonald, J. H., Handbook of biological statistics. Sparky House Publishing, Baltimore, Maryland,2008, pp:115-118.

[4] Finan, T.; Weidner, S.; Wong, K.; Buhrmester, J.; Chain, P.; Vorhölter, F.; Hernandez-Lucas, I.; Becker, A.; Cowie, A.; Gouzy, J.; Golding, B.; and Pühler, A., The complete sequence of the 1,683-kb pSymBmegaplasmid from the N2-fixing endosymbiontSinorhizobium melilotiProc. Natl. Acad. Sci. USA, 98(17)2001:9889-9894.

[5] Berg, W. K.; Cunningham, S. M.; Brouder, S. M.; Joern, B. C.; Johnson, K. D.; Santini, J. and Volenec, J. J, The long-term impact of phosphorus and potassium fertilization on alfalfa yield and yield components., Crop Sci. 47(5),2007: 2198-2209.

[6] Asanuma, S.; Ayanaba, A. and Munns, D. N, An agar plate method for rapid screening of Rhizobiumfor tolerance to acidaluminum stress .Soil Sci.Soc.Am.J., 47, 1983:256-258.

[7] Correa, O. S.; Aranda, A. and Barneix, A., Effects of $\mathrm{pH}$ on groeth and nodulation of two forage legumes. Journal of Plant Nutrition, 24(9),2001:1367-1375.

[8] Taté, R.; Ferraioli, S.; Filosa, S.; Cermola, M.; Riccio, A.; Iaccarino, M.; Patriarca, E. J., Glutamine utilization by Rhizobiumetli, Mol Plant Microbe Interact, 17(7)2004:720-728.

[9] Vincent, J. M. A manual for the practical atudy of root-nodule bacteria.International Biological Handbook No.15.BlackwellScientific Publications Ltd., Oxford.1970.

[10] Sanchez-Contreras, M.; Lloret, J.;Martyin, M.; Villacieros, M. and Bonilla, I., PCR Use of Highly Conserved DNA Regions for Identification of Sinorhizobiummeliloti. Applied and Environmental Microbiology, 66(8),2000:3621-3623.

[11] Khanuja, S. P. S. and Kumar, S., Isolation of phages for Rhizobium meliloti AK631. Ind. J. Biol. 26,1988:665-667.

[12] Engelke, T.; Jagadish, M. N. and Puhler, A., Biochemical and genetical analysis of Rhizobium meliloti mutants defective in C4dicarboxylate transport.,J. Gen. Microbiol., 133(11),1987:3019-3029.

[13] Geremia, R. A.; Cavaignac, S. ; Zorreguieta, A. ; Toro, N. ; Olivares, J. and Ugalde, R. A., A Sinorhizobiummelilotimutant that forms ineffective pseudonodules in alfalfa produces exopolysaccharide but fails to form B (1-2) glucan., J. Bacteriol., 169(2) 1987:880-884

[14] Nikanishi, I.; kimura, K.; Suzuki, Ishilkawa, M.; Banno, I.; Sakane, T. and Harada, T., Demonstration of curdlantypepolysaccharides and some other beta (1-3) glucan in microorganisms with aniline blue. J Gen.Appl.Microbiol. 22(2), 1976:1-11.

[15] Light, J. A.; Reed, J. W.; Hanks, J. F.; Hirsch, N.M. and Walker, G.C., Rhizobiummeliloti mutants that fail to succinylatetheircalcofluor-binding exopolysaccharide are defective in nodule invasion., Cell, 51(4),1987:579-587. 
[16] Swamynathan, S. K.; Singh, A., Pleiotropic effects of purineauxotrophy in Rhizobium meliloti on cell surface molecules. J. Biosci., 20(1),1995:17-28.

[17] Sambrook, J. and Rusell, D. W., Molecular cloning: a laboratory manual $3^{\text {rd }}$ ed. Cold Spring Harbor Laboratory Press, NewYork.2001

[18] Taté, R.; Riccio, A.; Caputo, E.; Iaccarino, M. and Patriarca, J., TheRhizobium etlimetZ gene is essential for methioninebiosynthesis and nodulation of Phaseolusvulgaris. Mol Plant-Microbe Interact 12(1)1999:24-34.

[19] Carter M. and Gibson A. H., Competitiveness and persistence of strains of rhizobia for faba bean in acid and alkaline soils. Soil Biol .Biochem.J .27(4)1995:617- 623.

[20] McDonald, J. H., Handbook of biological statistics. Sparky House Publishing, Baltimore, Maryland,2008, pp:115-118.

[21] Lepek, V. C. and D`antuono, A. L., bacterial surface polysaccharide and their role in rhizobia-legume association, Latus Newsletter, 36(1),2005:95-105.

[22] D'Antuono, A. L.; Casabuono, E.; Couto, A.; Uglade, R. A. and Lepek, V. L., Nodule development induced by Mesorhizobium loti mutant strain affected in polysaccharide synthesis. Molecular Plant-microbe Interactions 18(5),2005:446-457.

[23] Gomare, K. S.; Mese, M. and Shetkar, Y., Isolation of Rhizobium and cost effective production of biofertilizer. Indian J.L.Sci.,2(2),2013:49-53.

[24] Arnold, M. F. F.; Haag, A. F.; Capewell, S.; Boshoff,. H. I.; James, E. K.; McDonald, R.; Mair I.; Mitchell A. M.; Kerscher, B.; Mitchell, T. J.;Mergaert, P.; Barry III, C.; Scocchi, E. M.; Zanda, M. h.; Campopiano, D. J. and Ferguson, G. P, Partial complementation of SinorhizobiummelilotibacA mutant phenotypes by the Mycobacterium tuberculosisBacA protein, J Bacteriol., 195(2), 2013:389-98.

[25] Noel, K. D.; Box, J. M. and Bonne, V. J., 2-O-methyalion of fucosyl residues of a rhizobisl lipopolysaccharide is increased inresponse to host exudates and is eliminated in a symbiotically defective mutant. Applied and Environmentsl Microbiology, 70(3),2004:1537-1544

[26] Kannenberg, E. L.; Reuhs, B. L.; Forsberg, L. S. and Carlson, R. W., Lipopolysaccharides and K-antigens: their structures, biosynthesis, and functions. In Spaink H.P., Kondorosi A. and Hooykaas P.J.J. (Eds.) The Rhizobiaceae Molecular Biology of Model Plant-Associated Bacteria. ${ }^{\text {st }}$, Kluwer Academic Publishers, Dordrecht/Boston/London.1998, pp. 120-154.

[27] Kannenberg, E. L. and Carlson, R. W., Lipid A and O-chain modifications cause Rhizubium lipopolysaccharides to bexomehydrophopic during bacteoid development. Molecular Microbiology, 39(2)2001:379-391.

[28] Vedam, V.; Haynes, J. G.; Kannenberg, E. L.; Carlson, R. W. and Sherrier, D. R.., A Rhizobiumleguminosarumlipopolysaccharide lipid-A mutant induces nitrogen-fixing nodules with delayed and defective bacteroid formation. Molecular Plant-Microbe Interactions, 17(3),2004:283-291.

[29] Martin, M.; Lloret, J.; Sanchez-Contreras, M.; Bonilla, I. and Rivilla, R., MucR is necessary for galactoglucan production inSinorhizobiummeliloti EFB1..Mol. Plant-Microbe Interact., 13(1) 2000:129-135.

[30] Baev, N.; Endre, G.; Petrovics, G.; Banfalvi, Z. and Kondorosi, A, Six nodulation genes of nod box locus 4 in Rhizobiummeliloti are involved in nodulation signal production: nodM codes for d-glucosamine synthetase., Mol Gen Genet., 228(1-2), 1991:113-124.

[31] Keller, M.; Roxlau, A.; Weng, W. M.; Schmidt, M.; Quandt, J.; Niehaus, K.; Jording, D.; Arnold, W. and Pühler, A., Molecular analysis of the Rhizobium melilotimucR gene regulating the biosynthesis of the exopolysaccharidessuccynoglycan and galactoglucan. Mol Plant-Microbe Interact. 8,2006:267-277.

[32] Long, S. R.,Rhizobium symbiosis: Nod factors in perspective. Plant Cell, 8(10),1996:1885-1898.

[33] Schultze, M.; Kondorosi, E.; Ratet, P.; Buir'e, M. and Kondorosi, A., Cell and molecular biology of Rhizobium-plantinteractions. Int. Rev. Cytol., 156,1994:1-75.

[34] Brencic, A. and Winans, S., Detection of and response to signals involved in hostmicrobe interactions by plant-associated bacteria., Microbiology and Molecular Biology Reviews, 69(1),2005:155-194.

[35] Schultze, M. and Kondorosi, A., Regulation of symbiotic root nodule development. Annual Review of Genetics, 32(10), 1998:33-57.

[36] D'Haeze, W. and Holsters, M., Nod factor structures, responses, and perception during initiation of nodule development., Oxford Journals, 12(6),2002:79-105.

[37] Kondorosi, E. and Kondorosi, A., Nodule induction on plant roots by rhiozobia.TrendsBiochem. Sci., 11, 1986:296-299.

[38] Kondorosi, E.; Banfalvi, Z. and Kondorosi, A., Physical and genetic analysis of a symbiotic region of Rhizobium meliloti: identification of nodulation genes., Mol. Gen. Genet., 193(3),1984:445 -452.

[39] Horvath, B.; Kondorosi, E.; John, M.; Schmidt, J.; Torok, I.; Gyorgypal, Z.; Barabas, I.; Wieneke, U.; Schell, J. and Kondorosi, A., Organization, structure and symbiotic function of Rhizobium meliloti nodulation genes determining hostspecificityforalfalfa. Cell, 46(3), 1986:335-343.

[40] Graham, P. H.; Draeger. K. J.; Ferrey, M. L.; Conroy, M. J.; Hammer, B. E.; Martinez, E.; Aarons, S. R. and Quinto, C., AcidpH tolerance in strains of Rhizobium and Bradyrhizobium, and initial studies on the basis for acid tolerance of Rhizobium tropici UMR1899. Can. J. Microbiol. 40(10),1994:198-207.

[41] Soto, M. J.; Dillewijn, P.; Martínez-Abarca, F.; Jiménez-Zurdo, J. I. and Toro, N., Attachment to plant roots and nod geneexpression are not affected by $\mathrm{pH}$ or calcium in the acid-tolerant alfalfa-nodulating bacteria Rhizobium sp. LPU83. FEMS Microbiol Ecol. 48(1),2004:71-77.

[42] Del papa, M. F.; Balague, L.; Sowinski, W. C.; Segundo, E,; Abarca f. M.; Toro, N.; Niehaus, Niehaus.; Castro, S.; Pu“hler, A.;Aguilar, M.; Marti'nez-drets, G. and Lagares, A., Isolation and characterization of alfalfa-nodulating Rhizobia present in acidic soils of Central Argentina and Uruguay. Applied and Environmental Microbiology, 65(4),1999:1420-1427.

[43] Bordeleau, L. M. and Prévost, D.,Nodulation and nitrogen fixation in extreme environments. Plant and Soil,161(1),1994:115-125. 